\title{
The Possibilities of applying present-day Knowledge of Wine Aroma Components: Influence of several Juice Factors on Fermentation rate and Ester Production during Fermentation
}

\author{
A. C. HOUTMAN, J. MARAIS and C. S. DU PLESSIS \\ Oenological and Viticultural Research Institute, Private Bag X5026, Stellenbosch 7600 \\ Manuscript submitted: October 1979
}

\section{ABSTRACT}

The influence of several juice factors on fermentation and ester production was investigated to achieve a more satisfactory reproducibility of wine aroma composition. The contents of two acetates and three ethyl esters in the wine were used as the main analytical criteria. The factors which exerted the most marked influence on ester composition and fermentation were grape maturity, sugar content, fermentation temperature, and juice clarity. The cultivars examined exerted no noticeable differences.

\section{INTRODUCTION}

Esters are important aroma components of wine, and several studies have shown their correlation with wine quality (Wagener \& Wagener, 1968; Suomalainen, 1971; Du Plessis, 1975; Malik, 1975). Grapes contain very small quantities of them; they have their major origin in the fermentation process (Bezzubow, Pisarnitskii, Egorov \& Rodopulo, 1971; Suomalainen, 1971; Engan, 1974; Malik, 1975).

In pilot studies carried out at this Institute, large differences were observed in ester concentrations in representative and randomly chosen wines of each of six white cultivars. Furthermore, no significant differences could be established between average specific ester concentrations on a cultivar basis. These specific findings indicated that the cultivar, as such, excercises an insignificant effect on the pattern of ester synthesis during fermentation and is, in fact, secondary to known relevant factors such as i.a. juice composition and turbidity, oxygen, yeast strain and proliferation rate, as well as cellar technological conditions. The relevant literature in this field reveals apparent contradictions in respect of the influence of the abovementioned factors. Contradictions are to be expected if the effects of some of the pertinent variables are not taken into consideration. In view of these apparent anomalies it is necessary that individual variables be studied under less complex conditions and systems defined, which could lead to more reproduceable results.

Since the major portion of the aroma is formed during fermentation, it appears logical that the perceptibility of the cultivar character of a wine might be strongly dependent upon the composition of the fermentation aroma, which often dominates the grape bouquet. Ester concentrations and concentration ratios in the wine could be meaningfully used as sensitive indicators of the reproduceability of the fermentation process. A control of the process in such a manner that various gaschromatographic patterns can be pursued, will be useful in a standardisation of fermentation conditions and lead to greater diversity and consistently higher quality of wines. This study was aimed at the determination of must and technological factors which control ester production, and at the effect of these factors on the concentration of individual esters or groups of esters in the wine.

\section{MATERIALS AND METHODS}

\section{Materials}

Wines: To study the cultivar effect representative wine samples from the Cape wine show were obtained and analysed.

Juices:

Sequential series of 24 fermentations were carried out with free-run juice of grapes from one specific vineyard. The white wine cultivar most planted in South Africa, i.e. Chenin blanc, was chosen for this study. The grapes were harvested at different stages of maturity, crushed and $\mathrm{SO}_{2}$ added to $100 \mathrm{mg} / \ell$ and the juice partly de-acidified where necessary by the standard Acidex procedure to approximately $6 \mathrm{~g} / \ell$ total acidity (Table 1 ). The juice was settled for 24 hours under cooling at $5{ }^{\circ} \mathrm{C}$, the supernatant drawn off and held under nitrogen at $-12{ }^{\circ} \mathrm{C}$ until required. Thawing and homogenisation were also carried out under nitrogen.

To study the effect of clarity the following procedures were applied to obtain juice in 4 degrees of clarity, viz. $\mathrm{C}_{1}-\mathrm{C}_{4}$.

(a) The supernatant of settled juice was taken as such $\left(C_{1}\right)$.

(b) Juice $\mathrm{C}_{1}$ was coarsely filtered through a No. 3 cellulose-asbestos sheet $\left(\mathrm{C}_{2}\right)$.

(c) Juice $\mathrm{C}_{1}$ was centrifuged for $10 \mathrm{~min}$ at $8000 \times \mathrm{g}$ $\left(\mathrm{C}_{3}\right)$.

(d) Juice $\mathrm{C}_{1}$ was sterile filtered $\left(\mathrm{C}_{4}\right)$.

Extraction of finely suspended grape particulate matter: Four litres of settled juice $\left(C_{1}\right)$ were centrifuged for 10 min. at $8000 \times \mathrm{g}$. The wet grape particulate deposit $(18 \mathrm{~g})$ was macerated under nitrogen for one day at room temperature with $75 \mathrm{~m} \ell$ methanol. Subsequently $300 \mathrm{~m} \ell$ ether were added to the macerated mixture and again held for one day. The solid phase was filtered off and washed with 50 $\mathrm{m} \ell$ ether which was added to the filtrate.

The methanol and ether in the filtrate were evaporated at $40{ }^{\circ} \mathrm{C}$ and the fatty residue finally dried under vacuum. 
TABLE 1

Analytical data of Chenin blanc grape juices

\begin{tabular}{|c|c|c|c|c|c|c|c|}
\hline \multirow{2}{*}{ Sample No. } & \multirow{2}{*}{${ }^{\circ}$ Balling } & \multirow{2}{*}{$\begin{array}{c}\text { Reducing } \\
\text { Sugar } \\
(\mathrm{g} / \ell)\end{array}$} & \multirow{2}{*}{$\mathrm{pH}$} & \multirow{2}{*}{$\begin{array}{c}\text { Total* } \\
\text { acidity } \\
(\mathrm{g} / \ell)\end{array}$} & \multicolumn{2}{|c|}{$\mathrm{SO}_{2}(\mathrm{mg} / \ell)$} & \multirow{2}{*}{$\begin{array}{c}\alpha \text {-amino } \\
\text { nitrogen } \\
(\mathrm{mg} \mathrm{N} / \ell)\end{array}$} \\
\hline & & & & & free & total & \\
\hline 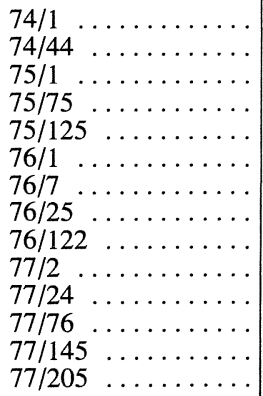 & $\begin{array}{l}14,7 \\
21,5 \\
13,6 \\
19,3 \\
22,5 \\
13,5 \\
20,0 \\
20,3 \\
22,7 \\
16,3 \\
17,7 \\
18,9 \\
20,6 \\
21,1\end{array}$ & $\begin{array}{l}140 \\
210 \\
126 \\
184 \\
220 \\
124 \\
176 \\
180 \\
220 \\
143 \\
168 \\
174 \\
195 \\
193\end{array}$ & $\begin{array}{l}3,36 \\
3,40 \\
3,85 \\
3,29 \\
3,46 \\
3,95 \\
3,51 \\
3,45 \\
3,30 \\
3,07 \\
3,15 \\
3,30 \\
3,20 \\
3,30\end{array}$ & $\begin{array}{r}6,9 \\
6,8 \\
5,4 \\
7,6 \\
5,8 \\
4,7 \\
6,3 \\
6,7 \\
6,0 \\
12,5 \\
9,1 \\
8,9 \\
8,0 \\
7,7\end{array}$ & $\begin{array}{l}36 \\
26 \\
34 \\
30 \\
24 \\
30 \\
36 \\
42 \\
41 \\
28 \\
28 \\
23 \\
18 \\
20\end{array}$ & $\begin{array}{l}91 \\
63 \\
88 \\
85 \\
88 \\
86 \\
74 \\
72 \\
88 \\
84 \\
70 \\
64 \\
46 \\
66\end{array}$ & $\begin{array}{l}- \\
\overline{125} \\
205 \\
240 \\
- \\
- \\
- \\
- \\
-\end{array}$ \\
\hline
\end{tabular}

*High acidity in relatively unripe grapes was partially neutralised.

This residue $(1,60 \mathrm{~g})$ was dissolved in $80 \mathrm{~m} \ell 96 \mathrm{vol} \%$ ethanol and 2,0 g Tween 80 added as emulsifier. Of this solution $5 \mathrm{~m} \ell$ were added to $1 \ell$ of the sterile filtered juice $\mathrm{C}_{4}$.

Juice lees additions: Free-run juice was settled and the lees separated from the supernatant. The supernatant was sterile filtered $\left(\mathrm{C}_{4}\right)$ and the separated lees added to this limpid juice on a volumetric basis.

Nutrilite and amino acid additions: The following nutrilites were added individually and in combination to samples at two to tenfold the concentrations $(\mathrm{mg} / \ell)$ reported for grapes (Ribéreau-Gayon \& Peynaud, 1964):

Biotin $(0,06)$; thiamine $(0,4)$; nicotinic acid $(4,0)$; pyridoxine $(1,0)$; inositol $(10,0)$ and pantothenic acid $(2,5)$.

Amino acid combinations were also added to individual samples as follows:

(Amino acid and $\mathrm{NH}_{4} \mathrm{C} 1$ additions are expressed in $\mathrm{mg}$ $\mathrm{N} / \ell)$.

(a) Leucine (16) + i-leucine (16) + threonine (16) + valine (16) + methionine (16).

(b) Arginine (60) + lysine (20).

(c) Tryptophane (25) + phenylalanine (30) + tyrosine (25).

(d) Asparagine (40) + glutamine (40).

(e) Ammonium chloride (80).

Yeast: A pure culture of Saccharomyces cerevisiae (WE 14) was used throughout. Unless otherwise noted propagation of the yeast culture was carried out in sterilized juice at $15^{\circ} \mathrm{C}$ for 8 days.

Inoculation: Inoculations were carried out under standard aerobic conditions or under nitrogen, which entailed the displacing of air with nitrogen immediately before and after inoculation. Apart from the initial displacement of air no further nitrogen was applied. Unless otherwise stated a $2,5 \%$ inoculation was carried out.

Fermentations: Fermentations were carried out at $11^{\circ}$ or $15{ }^{\circ} \mathrm{C}$ in $400 \mathrm{~m} \ell$ juice lots in $750 \mathrm{~cm}^{3}$ containers with double glass bulb fermentation caps.

Fermentation rate: The fermentation rate was expressed as the average daily $\mathrm{CO}_{2}$ mass loss (\%) from the first determinable loss $(0,5 \mathrm{~g} / \ell)$ to the point where a mass loss of $50 \%$ of the completed fermentation occurred.
Time of sample analysis: Since ester formation occurs at a relatively early stage of fermentation viz. the exponential phase (Nordström, 1965), samples were analysed on a comparative time basis. Samples exhibiting lengthy fermentation were analysed at the same time as faster fermenting samples i.e. on completion of the latter fermentations, except in the cases where the influence of time on ester formation was studied.

Yeast mass: Yeast mass was determined by weighing the moist yeast after centrifuging the $400 \mathrm{~m} \ell$ samples at 8000 $\times \mathrm{g}$ for $10 \mathrm{~min}$. and decanting the supernatant.

Ester determination: The following esters were determined: iso-amylacetate (AA), n-hexyl acetate (HA), ethyl caproate $\left(\mathrm{C}_{6} \mathrm{E}\right)$, ethyl caprylate $\left(\mathrm{C}_{8} \mathrm{E}\right)$, ethyl caprate $\left(\mathrm{C}_{10} \mathrm{E}\right)$, ethyl laurate $\left(\mathrm{C}_{12} \mathrm{E}\right)$ and 2-phenyl ethyl acetate (PEA).

Wines

Esters were determined quantitatively by gas chromatography. To $200 \mathrm{~m} \ell$ centrifuged wine a solution of $2,00 \mathrm{~m} \ell$ ethyl nonanoate $(0,050 \mathrm{~g} / \ell 96 \%$ ethanol) was added as internal standard. The esters were extracted with $3 \times 50$ $\mathrm{m} \ell$ ether, the combined ether extract was washed with $1 \times$ $40 \mathrm{~m} \ell 0,5 \mathrm{~N} \mathrm{NaOH}$, followed by $4 \times 40 \mathrm{m \ell} \mathrm{H}_{2} \mathrm{O}$ and subsequently dried overnight over anhydrous magnesium sulphate. The filtrate was concentrated to ca $0,5 \mathrm{~m} \ell$ in a waterbath at $40{ }^{\circ} \mathrm{C}$ and injected as such. The individual ester concentrations were calculated on a peak area basis (height $\times$ width at half height). The gas chromatography parameters were as follows:

Columns: $3 \mathrm{~m} \times 3 \mathrm{~mm}$ stainless steel.

Carrier phase: Chromosorb G. DMCS 60/80 mesh.

Stationary phase: Apiezon M, 5\%.

Tailing reducer: purified manoxol O.T. (3\% of stationary phase).

Carrier gas: $\mathrm{N}_{2}, 30 \mathrm{~m} \ell \mathrm{min}^{-1}$.

Temperature program: $60{ }^{\circ} \mathrm{C}$ for $15 \mathrm{~min}$., raised at $6{ }^{\circ} \mathrm{C}$ per minute to $120^{\circ} \mathrm{C}, 120^{\circ} \mathrm{C}$ for $8 \mathrm{~min}$., raised at $7,5^{\circ} \mathrm{C}$ per min. to $180{ }^{\circ} \mathrm{C}$.

Detector: flame ionization.

Yeast

Subsequent to the mass determination of the freshly centrifuged yeast, it was mixed with a $60 \mathrm{~m} \ell$ methanol 15 $\mathrm{m} \ell$ ether mixture and kept for 3 days at $-12{ }^{\circ} \mathrm{C}$. After filtering off the yeast through a fine glass filter and 
washing with $20 \mathrm{~m} \ell$ fresh methanol/ether mixture, two further 3-day extractions at $-12{ }^{\circ} \mathrm{C}$ were made, once with $60 \mathrm{~m} \ell$ methanol/ether (1:1) mixture and finally with $60 \mathrm{~m} \ell$ ether. Subsequently $2,00 \mathrm{~m} \ell$ of ethyl nonanoate internal standard solution $(1,00 \mathrm{~g} / \ell 96 \%$ ethanol) were added to the extracts and washings. The solution was washed with $1 \times$ $50 \mathrm{~m} \ell 0,5 \mathrm{~N} \mathrm{NaOH}$ and $4 \times 70 \mathrm{~m} \ell$ water to remove the methanol and subsequently concentrated to ca $10 \mathrm{~m} \ell$ in a waterbath at $40{ }^{\circ} \mathrm{C}$ and washed with $5 \mathrm{ml}$ water. The extract was used as such and quantitation carried out as before.

\section{RESULTS AND DISCUSSION}

Variation in ester concentrations in wine and yeast during fermentation: The final concentration of an ester in a wine is dependent i.a. on its formation and destruction during the fermentation process and on its distribution between the wine and the yeast as shown in Fig. 1 and Table 2. The stage of maximum ester content under the conditions of this study $\left(11^{\circ} \mathrm{C}\right)$ occurred $2-3$ weeks after the onset of fermentation. Subsequent to this stage a decrease occurred which was most marked in the cases of $A A$ and $C_{6} E$. Decreases in especially PEA, $C_{8} E$ and $C_{10} E$ were not as high. In addition to chemical stability the relatively high concentrations of the latter two esters in the yeast cell itself (Table 2) are possibly contributory to this phenomenon in the stabilising effect which they exert on the relatively constant values of these esters in the wine. In this respect it must be noted that due to the increasing apolarity of the higher esters their relative concentration increases in the yeast cell and decreases in the wine. The $\mathrm{C}_{12} \mathrm{E}$ ester e.g. is present in the cell in amounts up to 50 times more than in the wine (Table 2). Similar findings in beer have been reported (Nykänen, Nykänen \& Suomalainen, 1977).

Cultivar effect: The influence of white cultivars on ester formation is shown in Table 3. It is clear that marked variations occurred in the ester concentrations within each cultivar and, furthermore, that these concentration ranges of the cultivar overlap to such an extent that the cultivar effects could not be differentiated by visual examination of standard deviations.

Nutrilite and amino acid effect: The influence of amino acids on yeast growth and ester formation has been reported by several authorities. Studies concerning this aspect were carried out on juices $75 / 1,75 / 75$ and $75 / 125$, of which the $\alpha$-amino nitrogen contents are given in Table 1. Apart from the known effects, such as the direct

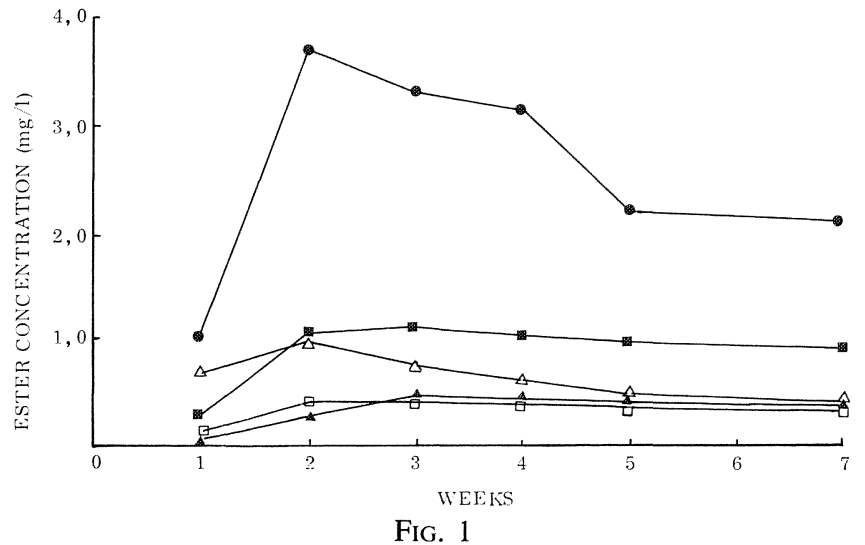

Development of ester concentrations in Chenin blanc must during a seven week period of fermentation and yeast contact. (Grape juice $74 / 44, C_{1}$, inoculated with $5 \%$ yeast culture under anaerobic conditions, was fermented at $11^{\circ} \mathrm{C}$.

\section{$\triangle$ Ethyl caproate \\ Ethyl caprylate \\ Athyl caprinate \\ i-Amyl acetate \\ 2-Phenyl ethyl acetate}

stimulation of ester formation by addition of precursors, for instance the production of PEA from phenylalanine, no indirect effect was observed on the production of other esters such as the fatty acid ethyl esters. It was found that the juice material studied obviously contained sufficient of these nutrilites and nutrients for optimal ester production. These findings confirm those of Harvalia (1976) viz. that ester composition of wines was not significantly related to the amino acid composition of musts in general fermentation practice since musts normally contain adequate concentrations of these components.

Grape maturity and sugar content of juice: The influence of grape maturity on ester formation was studied on juices $74 / 1$ and 74/44 whose sugar contents were 140 and $210 \mathrm{~g} / \ell$ respectively (Table 1 ). The influence of sugar as a prominent factor in maturity on this facet was investigated by the addition of glucose as indicated in Table 4A. Increasing the sugar content of juice $74 / 1$ to that of $74 / 44$ effects significant increases in the concentration of both ethyl and acetate esters (Table 4A, columns 1 and 2 and Table 4B). Sugar addition to juice 74/1 (immature) had the same effect on ethyl ester formation as grape maturation. Their concentrations in the wine were to all intents identical with those formed by fermentation of juice $74 / 44$; in fact, no significant differences were shown (Table 4A, columns 2 and 3 ).

TABLE 2

Distribution of esters between the wine and yeast phases at three stages of fermentation* of Chenin blanc juice

\begin{tabular}{|c|c|c|c|c|c|c|c|c|c|}
\hline \multirow{3}{*}{$\begin{array}{l}\text { Ester concen- } \\
\text { trations } \\
\text { (mg/litre } \\
\text { fermenting } \\
\text { liquid) }\end{array}$} & \multicolumn{9}{|c|}{ Weeks after inoculation } \\
\hline & \multicolumn{3}{|c|}{2} & \multicolumn{3}{|c|}{4} & \multicolumn{3}{|c|}{7} \\
\hline & $\begin{array}{l}\text { in } \\
\text { wine }\end{array}$ & $\begin{array}{c}\text { in } \\
\text { yeast }\end{array}$ & total & $\begin{array}{l}\text { in } \\
\text { wine }\end{array}$ & $\begin{array}{c}\text { in } \\
\text { yeast }\end{array}$ & total & $\begin{array}{l}\text { in } \\
\text { wine }\end{array}$ & $\begin{array}{c}\text { in } \\
\text { yeast }\end{array}$ & total \\
\hline $\begin{array}{l}\mathrm{AA} \ldots \ldots \\
\mathrm{PEA} \ldots \ldots \\
\mathrm{C}_{6} \mathrm{E} \ldots \ldots \\
\mathrm{C}_{8} \mathrm{E} \ldots \ldots \\
\mathrm{C}_{10} \mathrm{E} \ldots \ldots \\
\mathrm{C}_{12} \mathrm{E} \ldots \ldots\end{array}$ & $\begin{array}{l}3,70 \\
0,41 \\
1,00 \\
1,00 \\
0,30 \\
0,06\end{array}$ & $\begin{array}{l}0,0 \\
0,0 \\
0,0 \\
0,95 \\
2,70 \\
1,05\end{array}$ & $\begin{array}{l}3,70 \\
0,41 \\
1,00 \\
1,95 \\
3,00 \\
1,11\end{array}$ & $\begin{array}{l}3,15 \\
0,39 \\
0,62 \\
1,00 \\
0,40 \\
0,03\end{array}$ & $\begin{array}{l}0,0 \\
0,0 \\
0,0 \\
1,25 \\
7,40 \\
1,65\end{array}$ & $\begin{array}{l}3,15 \\
0,39 \\
0,62 \\
2,25 \\
7,80 \\
1,68\end{array}$ & $\begin{array}{l}2,10 \\
0,36 \\
0,44 \\
0,90 \\
0,40 \\
0,04\end{array}$ & $\begin{array}{l}0,0 \\
0,0 \\
0,0 \\
1,10 \\
7,70 \\
2,00\end{array}$ & $\begin{array}{l}2,10 \\
0,36 \\
0,44 \\
2,00 \\
8,10 \\
2,04\end{array}$ \\
\hline
\end{tabular}

*Anaerobic inoculation and fermentation at $11^{\circ} \mathrm{C}$. 
TABLE 3

*Range of ester concentrations in six white cultivar wines

\begin{tabular}{|c|c|c|c|c|c|c|}
\hline \multirow[b]{2}{*}{ Ester } & \multicolumn{6}{|c|}{ Cultivar } \\
\hline & $\begin{array}{l}\text { Chenin } \\
\text { blanc } \\
(\mathrm{mg} / \ell)\end{array}$ & $\begin{array}{l}\text { Riesling } \\
(\mathrm{mg} / \ell)\end{array}$ & $\begin{array}{l}\text { Palomino } \\
(\mathrm{mg} / \ell)\end{array}$ & $\begin{array}{l}\text { Semillon } \\
(\mathrm{mg} / \ell)\end{array}$ & $\begin{array}{c}\text { Clairette } \\
\text { blanche } \\
(\mathrm{mg} / \ell)\end{array}$ & $\begin{array}{l}\text { Colombard } \\
(\mathrm{mg} / \ell)\end{array}$ \\
\hline 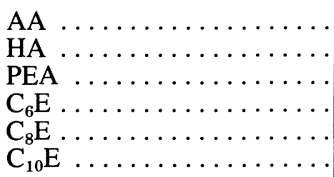 & $\begin{array}{l}2,0-9,2 \\
0,10-0,42 \\
0,09-0,30 \\
0,65-1,05 \\
1,50-2,30 \\
0,37-0,65\end{array}$ & $\begin{array}{l}2,7-7,4 \\
0,14-0,32 \\
0,15-0,33 \\
0,70-1,25 \\
1,75-2,60 \\
0,42-0,60\end{array}$ & $\begin{array}{l}3,6-7,5 \\
0,05-0,34 \\
0,13-0,39 \\
0,85-1,60 \\
1,95-2,65 \\
0,39-0,73\end{array}$ & $\begin{array}{l}0,8-8,0 \\
0,04-0,25 \\
0,05-0,30 \\
0,55-1,20 \\
1,45-2,45 \\
0,35-0,73\end{array}$ & $\begin{array}{l}4,5-15,9 \\
0,28-0,65 \\
0,23-0,48 \\
0,90-1,45 \\
2,00-2,70 \\
0,45-0,80\end{array}$ & $\begin{array}{l}3,0-10,2 \\
0,16-0,39 \\
0,17-0,39 \\
0,70-1,30 \\
1,95-2,40 \\
0,43-0,60\end{array}$ \\
\hline
\end{tabular}

*Six samples of each cultivar.

In respect of the acetate ester concentrations in the wine, AA and PEA show a significant decrease as a result of increased grape maturity (Table 4A, columns 1 and 3 ). In the case of these acetates this maturation effect cannot be attributed to the increase in sugar content since elevated sugar content and grape maturity have the opposite effect in this case (Table 4A, columns 1, 2 and 3). Increasing the sugar content of the more mature grape juice $74 / 44$ to 230 $\mathrm{g} / \ell$ induced a further increase in the concentration of both acetate and ethyl esters in the wine, although significance was only shown with respect to $\mathrm{AA}, \mathrm{C}_{8} \mathrm{E}$ and $\mathrm{C}_{10} \mathrm{E}$ (Table $4 \mathrm{~A}$, columns 3 and 4). The influence of sugar on ester formation was re-examined on juice 76/1. Relevant data are given in Table 5 . With sugar content as the only variable an increase in this component confirmed the former data, viz. both acetate and ethyl esters increased significantly in the wine with increasing must sugar content (Table 5). As a point of interest it was noted here that, under these conditions, the sugar content had no effect on the rate of fermentation even at the high concentration of $274 \mathrm{~g} / \ell$.
A possible explanation for the increase in the more apolar esters e.g. $\mathrm{C}_{8} \mathrm{E}$ and $\mathrm{C}_{10} \mathrm{E}$, may be found in the increased wine alcohol content with the higher sugar concentration in the juice. Under these conditions the higher ethanol concentrations could promote formation of the ethyl esters as well as raise the solubility of this specific group of esters in the wine. Especially in view of the large concentrations of these esters in the yeast itself, their partition coëfficients in the wine phase/yeast lipid phase are important. In the case of more elevated ethanol concentrations these coëfficients will alter in favour of the wine phase. Although grape sugar content has been shown to influence ester formation, the stage of maturity of the grape, as seen apart from its sugar content, has also been indicated as influencing acetate but not ethyl ester formation. It is clear that there are unknown factors whose influence, especially upon the acetate ester production, varies during the ripening of the grape.

Juice clarity, yeast growth and rate of fermentation in relation to ester production: Several authors, especially Nordström (1965), have emphasised the close

TABLE 4A

*Influence of grape maturity and sugar level on concentration of esters in the Chenin blanc wine

\begin{tabular}{|c|c|c|c|c|}
\hline \multirow{3}{*}{$\begin{array}{l}\text { Column No. } \\
\text { Glucose addition }(g / \ell) \\
\text { Final sugar concentration }(g / \ell)\end{array}$} & \multicolumn{2}{|c|}{$\begin{array}{l}\text { Immature grape juice } \\
74 / 1\left(C_{1}\right)\end{array}$} & \multicolumn{2}{|c|}{$\begin{array}{l}\text { Mature grape juice } \\
77 / 44\left(\mathrm{C}_{1}\right)\end{array}$} \\
\hline & 1 & 2 & 3 & 4 \\
\hline & $\begin{array}{c}0 \\
140\end{array}$ & $\begin{array}{r}70 \\
210\end{array}$ & $\begin{array}{r}0 \\
210\end{array}$ & $\begin{array}{r}30 \\
240\end{array}$ \\
\hline 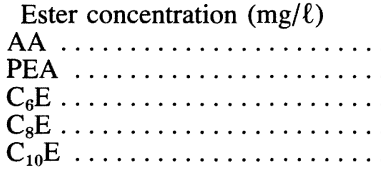 & $\begin{array}{l}3,02 \\
0,36 \\
0,56 \\
0,73 \\
0,32\end{array}$ & $\begin{array}{l}3,96 \\
0,55 \\
0,69 \\
1,07 \\
0,46\end{array}$ & $\begin{array}{l}1,87 \\
0,27 \\
0,67 \\
1,07 \\
0,42\end{array}$ & $\begin{array}{l}2,13 \\
0,29 \\
0,71 \\
1,15 \\
0,50\end{array}$ \\
\hline
\end{tabular}

*5\% yeast inoculation under nitrogen, fermented at $11^{\circ} \mathrm{C}$. Average ester values of 6 replicates.

TABLE 4B

Statistical significance of the differences between the ester concentrations in Chenin blanc wines, due to grape maturity and sugar content variations ${ }^{a}$

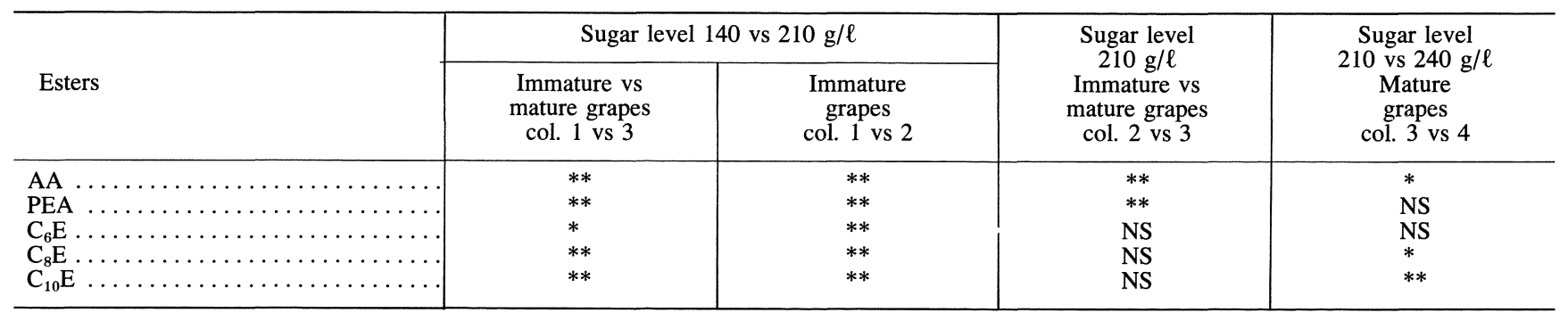

a Data from Table 4A.

* Significant at $95 \%$ confidence level.

** Significant at $99 \%$ confidence level.

NS Not significant. 
TABLE 5

Sugar contents in juice and correlations with ester concentrations in Chenin blanc wines

\begin{tabular}{|c|c|c|c|c|c|c|}
\hline $\begin{array}{l}\text { Glucose addition }(\mathrm{g} / \ell) \\
\text { Final must sugar content }(\mathrm{g} / \ell)\end{array}$ & $\begin{array}{r}0 \\
124\end{array}$ & $\begin{array}{r}30 \\
154\end{array}$ & $\begin{array}{r}60 \\
184\end{array}$ & $\begin{array}{l}120 \\
244\end{array}$ & $\begin{array}{l}150 \\
274\end{array}$ & $\begin{array}{l}\text { Correlation } \\
\text { coëfficient } \\
\text { (r) }\end{array}$ \\
\hline 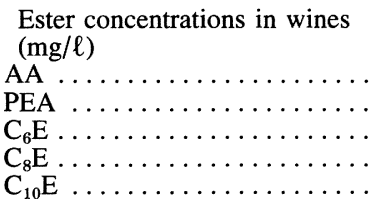 & $\begin{array}{l}2,00 \\
0,23 \\
0,44 \\
0,35 \\
0,13\end{array}$ & $\begin{array}{l}2,85 \\
0,31 \\
0,39 \\
0,32 \\
0,15\end{array}$ & $\begin{array}{l}3,50 \\
0,31 \\
0,50 \\
0,42 \\
0,15\end{array}$ & $\begin{array}{l}4,15 \\
0,40 \\
0,53 \\
0,54 \\
0,24\end{array}$ & $\begin{array}{l}5,15 \\
0,42 \\
0,64 \\
0,47 \\
0,28\end{array}$ & $\begin{array}{l}0,98 * * \\
0,97 * * \\
0,90 * * \\
0,85 * \\
0,97 * *\end{array}$ \\
\hline
\end{tabular}

Grape juice $76 / 1\left(95 \% \mathrm{C}_{4}+5 \% \mathrm{C}_{1}\right)$.

Inoculated with $5 \%$ yeast under aerobic conditions; fermentation temperature $11{ }^{\circ} \mathrm{C}$

*Significant at $95 \%$ confidence level.

**Significant at $99 \%$ confidence level.

relationship between yeast mass, fermentation rate and ester production. These relationships were consequently studied on juice $76 / 7$, and relevant data are given in Tables $6 \mathrm{~A}$ and $\mathrm{B}$. It is clear that a highly significant correlation existed between yeast mass and fermentation rate. Furthermore, except for the $\mathrm{C}_{6} \mathrm{E}$ ester the concentrations of both acetate and ethyl esters correlate highly significantly with both fermentation rate and yeast mass.

The latter parameters were, as a result of these findings, also incorporated into a study on the effect of juice clarity on ester formation. The influence on fermentation tempo, effected by different degrees of juice turbidity under anaerobic conditions, is shown in Fig. 2. The fermentation of sterile filtered juice $\left(C_{4}\right)$ is, relative to the settled juice $\left(C_{1}\right)$, markedly slower. The fermentation curves of coarse filtered $\left(\mathrm{C}_{2}\right)$ and centrifuged $\left(\mathrm{C}_{3}\right)$ juice were approximately the same and located between $\mathrm{C}_{1}$ and $\mathrm{C}_{4}$. The strong retardation of the fermentation of the $\mathrm{C}_{4}$ juice was completely cancelled out by the addition of $10 \% \mathrm{C}_{1}$ juice.

The addition of a small amount of turbidity to the $\mathrm{C}_{4}$ juice, which was scarcely visible, was evidently sufficient to promote a considerable yeast activity. Subsequent repeat studies carried out with juice from grapes of different stages of maturity confirmed these results.

Data on the influence of juice clarity on ester formation together with relevant fermentation rates and yeast mass are given in Table 6A. It is clear that the addition of the very small amount of turbidity contained in the relatively clear settled juice $\left(C_{1}\right)$ to the limpid filtered juice $\left(C_{4}\right)$ effects a significant increase in the two acetate esters and $\mathrm{C}_{8} \mathrm{E}$ and $\mathrm{C}_{10} \mathrm{E}$. The $\mathrm{C}_{6} \mathrm{E}$ ester does not appear to be affected. The exceptional effectiveness of the small turbidity particles in the juice in causing ester increments is further illustrated in the comparison between the data of

TABLE 6A

Influence of juice clarity on fermentation rate, yeast mass and ester formation in Chenin blanc wines ${ }^{a}$

\begin{tabular}{|c|c|c|c|c|c|}
\hline \multirow{2}{*}{$\begin{array}{l}\text { Column No. } \\
\text { Juice clarities }\end{array}$} & \multirow{2}{*}{$\stackrel{1}{\mathrm{C}_{4}}$} & \multirow{2}{*}{$\begin{array}{c}2 \\
90 \% \mathrm{C}_{4} \\
+10 \% \mathrm{C}_{1}\end{array}$} & \multirow{2}{*}{$\begin{array}{c}3 \\
\mathrm{C}_{1}\end{array}$} & \multicolumn{2}{|c|}{$\mathrm{F}$} \\
\hline & & & & $\begin{array}{l}\text { col. } 1 \text { vs } \\
\text { col. } 2\end{array}$ & $\begin{array}{l}\text { col. } 2 \text { vs } \\
\text { col. } 3\end{array}$ \\
\hline 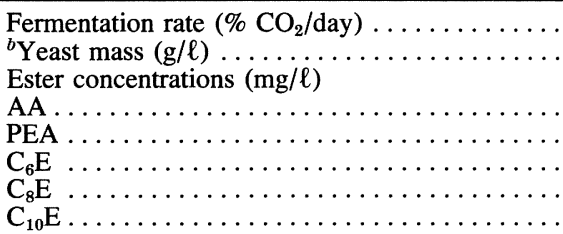 & $\begin{array}{l}3,75 \\
5,1 \\
2,65 \\
0,30 \\
1,38 \\
0,51 \\
0,17\end{array}$ & $\begin{array}{l}11,1 \\
10,4 \\
\\
8,05 \\
0,85 \\
1,42 \\
0,86 \\
0,34\end{array}$ & $\begin{array}{l}11,1 \\
11,0 \\
\\
9,05 \\
1,00 \\
1,35 \\
0,91 \\
0,34\end{array}$ & $\begin{array}{c}415^{* *} \\
25^{* *} \\
\\
94^{* *} \\
43^{* *} \\
\mathrm{NS} \\
7,2^{*} \\
30^{* *}\end{array}$ & $\begin{array}{l}\text { NS } \\
\text { NS } \\
\text { NS } \\
\text { NS } \\
\text { NS } \\
\text { NS } \\
\text { NS }\end{array}$ \\
\hline
\end{tabular}

a Averaged values of 8 replicates; grape juice $76 / 7$

Inoculated under anaerobic conditions.

Fermentation temperature $15^{\circ} \mathrm{C}$.

$b$ Yeast masses corrected for suspended grape material.

* Significant at $95 \%$ confidence level $(\mathrm{F}=5,59)$.

** Significant at $99 \%$ confidence level $(\mathrm{F}=12,25)$.

NS Not Significant.

TABLE 6B

Correlations between rate of fermentation, yeast mass and concentrations of esters ${ }^{a}$

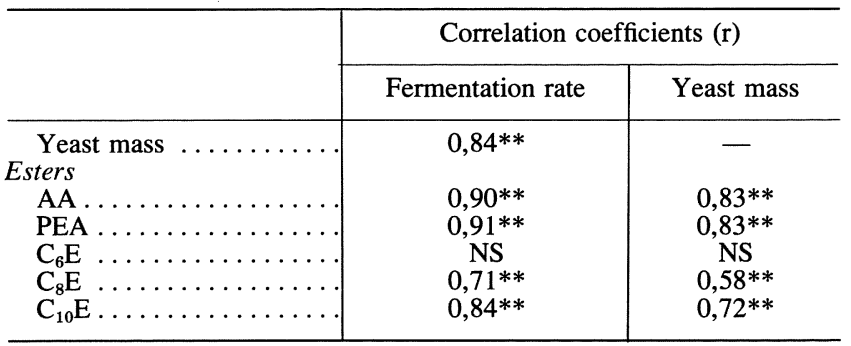

a Data from Table 6A. columns 2 and 3 of Table 6A. The differences between ester concentrations are in this case insignificant, and consequently a small amount of this material appears to be sufficient to bring about the maximum changes in yeast growth, fermentation rate and ester formation. It appears that the settled must $\left(C_{1}\right)$ contained at least a ten-fold surplus of the critical quantities of this material. Confirmatory results were obtained in subsequent repeat studies on juices from the same vineyard but different years, viz. 76/1, 25 and 122 and 77/2, 76 and 205. Enhanced ester production can be attributed to the stimulated yeast proliferation and fermentation, especially during the exponential phase of fermentation, and is therefore in all probability an indirect result of the influence of the suspended grape material. 
In the light of the recent investigations of Aries \& Kirsop (1977) on the relations between ergosterol and yeast proliferation, a connection between the growth promoting acitivity of these suspended grape particles and ergosterol seems probable. On this basis it appeared likely that an active fraction should be extractable from the solid particles. Grape particulate was consequently extracted for an apolar fraction and its effect noted on the fermentation rate. These findings are given in Fig. 3 . It is clear that the extract from the suspended material in $0,25 \ell C_{1}$ juice, had a marked influence on raising the fermentation rate of 1 litre of $\mathrm{C}_{4}$ juice to a rate very close to that of the settled juice $\left(C_{1}\right)$. It was considerably more effective than the residue remaining after extraction. These initial findings demonstrate that at least one causal factor in the positive influence of turbidity on fermentation is based on extractable components contained in or adsorbed by the grape particulate of settled juice $\left(C_{1}\right)$.

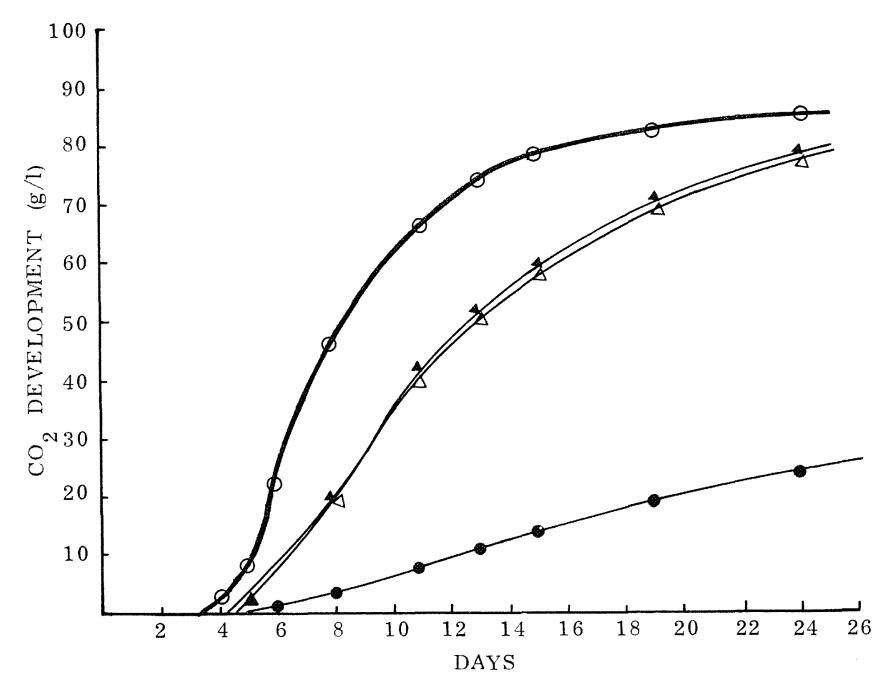

FIG. 2

Influence of varying degrees of Chenin blanc juice clarity on fermentation pattern. (Juice 76/7, inoculated under anaerobic conditions with $0,5 \%$ yeast culture. Fermentation temperature $\left.15^{\circ} \mathrm{C}\right)$.

juice clarity $\mathrm{C}_{4}$

$\triangle$ juice clarity $C_{3}$

$\Delta$ juice clarity $\mathrm{C}_{2}$

juice clarity $C_{1}$ as well as $90 \% C_{4}+10 \% C_{1}$

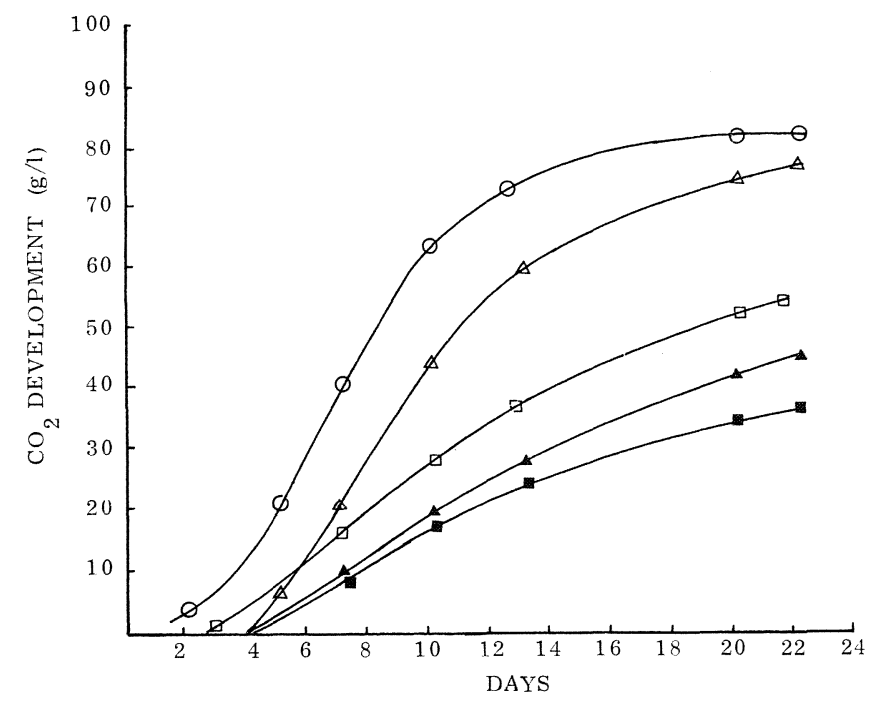

FIG. 3

Fermentation promoting influence of grape particulate extract (GPE) of juice 77/24. (Inoculated under anaerobic conditions with $2,5 \%$ yeast culture. Fermentation temperature $15{ }^{\circ} \mathrm{C}$ ).

- $\mathrm{C}_{4}$ juice $+5 \mathrm{ml}$ ethanol

$\Delta \mathrm{C}_{4}$ juice $+0,20 \mathrm{~g} / 1$ Tween 80 in $5 \mathrm{ml}$ ethanol

$\Delta \mathrm{C}_{4}$ juice $+0,2 ; 0 \mathrm{~g} / 1$ Tween $80+0,16 \mathrm{~g} / 1 \mathrm{GPE}$ in $5 \mathrm{ml}$ ethanol

$\square \mathrm{C}_{4}$ juice + the residue of the extraction mentioned under $\Delta+$ $5 \mathrm{ml}$ ethanol

$\mathrm{C}_{1}$ juice

Juice lees in relation to ester production: The presence of small amounts of finely suspended grape particulate has been shown to be critical in relation to fermentation and ester production. In the course of wine making a considerable amount of coarse material is precipitated during the settling process. On the basis of the foregoing it appeared important that the influence of this material should also be studied in the context of ester formation. Data on this study are presented in Table 7. It will be noted, and as could be expected from the previous findings, that 1 to $2 \%$ addition of juice lees effected a clear increase in ester production. However, from $5 \%$ progressively larger additions caused significant and related decreases in ester concentrations. Relevant literature concerning the production of esters and higher alcohols often reported apparently contradictory findings. This study has indicated that such anomalies could be influenced by

TABLE 7

Influence of varying lees admixtures with limpid juice upon ester formation in Chenin blanc wines ${ }^{a}$

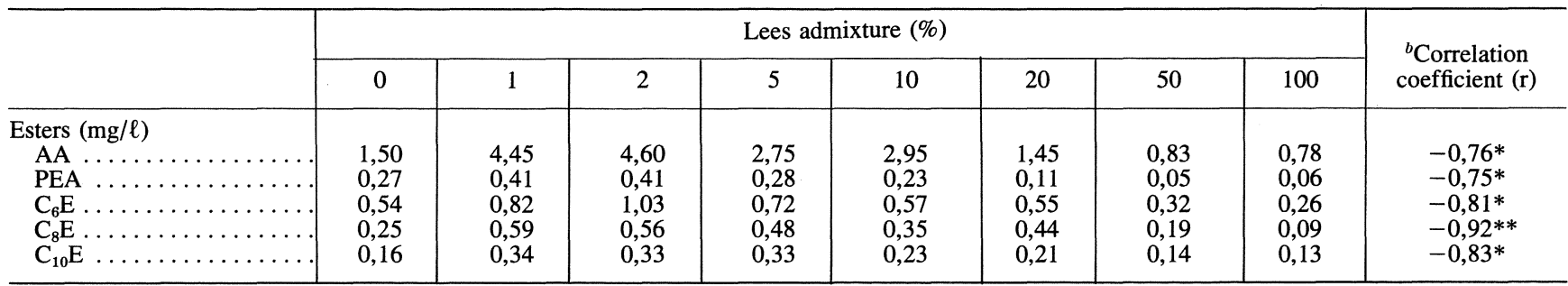

Grape juice $76 / 1, \mathrm{C}_{4}$ admixed with the lees of free run juice $76 / 1$ settled for 24 hours (resulting in 11 vol. $\%$ lees +89 vol. $\%$ juice $\mathrm{C}_{1}$ ). Inoculated with $5 \%$ yeast under anaerobic conditions.

Fermentation temperature $11^{\circ} \mathrm{C}$.

${ }_{b}$ Correlation coefficients are calculated over the $2-100 \%$ lees admixtures $\left(98-0 \%\right.$ juice $\mathrm{C}_{4}$ ) between percentage admixture and ester concentration.

* Significant at $95 \%$ confidence level $(\mathrm{P} 0,05)$.

** Significant at $99 \%$ confidence level (P 0,01). 
factors operative in systems which are not sufficiently clearly defined. It has been shown that factors such as grape maturity, sugar content of the juice and, especially, grape particulate material are important in this respect. Very little work has been published on the turbidity factor. In view of the marked effects which it can bring about on wine aroma components it is seen as an aspect which needs further study, especially in connection with ester production and organoleptically determined wine quality.

Fermentation temperature: The influence of temperature on ester formation in sterile filtered juices (74/1. $\mathrm{C}_{4}$, 74/44. $C_{4}$ and 75/1. $C_{4}$ ) inoculated under nitrogen is shown in Table 8. It is clear that the concentration of the acetate esters AA and PEA increase when the fermentation temperature was increased from $11{ }^{\circ} \mathrm{C}-15^{\circ} \mathrm{C}$. The formation of $\mathrm{C}_{6} \mathrm{E}, \mathrm{C}_{8} \mathrm{E}$, and $\mathrm{C}_{10} \mathrm{E}$ also manifests the effect of temperature and production thereof attains a maximum in the 15 ${ }^{\circ} \mathrm{C}$ series.

TABLE 8

Ester concentrations in wines in relation to the fermentation temperatures

\begin{tabular}{|c|c|c|}
\hline \multirow[b]{2}{*}{ Esters $(\mathrm{mg} / \ell)$} & \multicolumn{2}{|c|}{ Fermentation temperature $\left({ }^{\circ} \mathrm{C}\right)$} \\
\hline & 11 & 15 \\
\hline 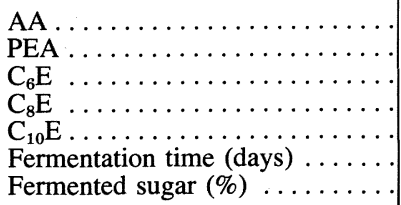 & $\begin{array}{l}1,70 \\
0,22 \\
0,68 \\
0,42 \\
0,38 \\
60 \\
84\end{array}$ & $\begin{array}{l}5,20 \\
0,46 \\
1,15 \\
0,70 \\
0,52 \\
27 \\
98\end{array}$ \\
\hline
\end{tabular}

\section{LITERATURE}

ARIES, V. \& KIRSOP, B. H., 1977. Sterol synthesis in relation to growth and fermentation by brewing yeasts inoculated at different concentrations J. Ins. Brew. 83, 220-223.

BEZZUBOW, A., PISARNITSKII, A. F., EGOROV, I. A. \& RODOPULO, A. K., 1971. Aetherische Öle der Trauben und ihre Veränderung während der Gärung. Vinodel. $i$ Vinogradar. 31, 59-62; (Abstr. Vitis. 11, 152, 1972).

DU PLESSIS, C. S., 1975. Fermentation formed components in relation to wine quality. 4th International Enological Symposium, Valencia, Spain, 374-390.

ENGAN, S., 1974. Esters in beer. Brewers' Digest 49, 40-42, 44, 46-48.

HARVALIA, A., 1976. Relation entre la teneur des vins en alcools superieurs et la teneur des moûts en substances azotées en particulier en acides aminés. Bull. OIV 49, 222-233.

MALIK, F., 1975. Wine flavour and its perception by humans. Vinohrad 13, 88-89; (Abstr. FSTA 8 H89 (1976)).

NORDSTRÖM, K., 1965. Possible control of volatile ester formation in brewing. Proc. Europ. Brew. Conv., Stockholm, 195-208.

NYKÄNEN, L. NYKANEN, I. \& SUOMALAINEN, H. 1977. Distribution of esters produced during sugar fermentation between the yeast cell and the medium J. Inst. Brew. $83,32-34$.

RIBÉREAU-GAYON, J. \& PEYNAUD, E., 1964. Traité d'Oenologie I, p. 113. Paris: Librairie Polytechnique Beranger.

SUOMALAINEN, H., 1971. Yeast and its effect on the flavour of alcoholic beverages. J. Inst. Brew. 77, 164-177.

WAGENER, W. W. D. \& WAGENER, G. W. W., 1968. The influence of ester and fusel alcohol content upon the quality of dry white wine. S. Afr. J. Agr. Sci. 11, 496-476. 